http://doi.org/10.35784/iapgos.2654

\title{
BATTERY SWAPPING STATIONS FOR ELECTRIC VEHICLES
}

\author{
Aleksander Chudy \\ Lublin University of Technology, Department of Electrical Engineering and Electrotechnologies, Lublin, Poland
}

Abstract. Battery swapping is a promising technology when compared with the traditional electric vehicle charging stations. The time spent at a battery swapping station might be similar to the time spent at a filling station. The article presents information on attempts to implement this solution, methods of battery swapping, infrastructure and operation of battery swapping stations, as well as the benefits and key challenges of the battery swapping technology.

Keywords: battery swapping, battery swapping stations, electromobility, electric vehicles

\section{STACJE WYMIANY AKUMULATORÓW SAMOCHODÓW ELEKTRYCZNYCH}

Streszczenie. Wymiana akumulatorów samochodów elektrycznych to obiecująca technologia w stosunku do tradycyjnego podejścia do stacji ładowania samochodów elektrycznych, ponieważ czas spędzony na stacji wymiany akumulatorów może być podobny do czasu spędzonego na stacji benzynowej. $W$ artykule przedstawiono informacje na temat prób implementacji tego rozwiązania, sposobów wymiany akumulatorów, infrastruktury i działania stacji wymiany akumulatorów oraz korzyści i kluczowych wyzwań tego rozwiązania.

Słowa kluczowe: wymiana akumulatorów; stacje wymiany akumulatorów; elektromobilność; samochody elektryczne

\section{Introduction}

The development of electric vehicles (EVs) is widely popularised by their owners, EVs manufacturers, global governments and investors mainly due to the ability to reduce carbon dioxide emissions and thus reduce the environmental impact of the transport sector. The increasing penetration of electric vehicles has the potential to reduce pollutant emissions and reduce the consumption of conventional fuels. Moreover, EVs can also contribute to increasing the use of renewable energy sources such as wind and solar energy sources as the batteries in electric cars are capable of storing electricity [6].

Charging EVs' batteries plays a key role in the adaptability of electromobility. The current charging process mainly involves connecting an EV to a household electrical outlet or charging station and leaving it on for a few hours. This method requires much more time than refueling a vehicle with an internal combustion engine and is a serious barrier to the popularisation of EVs. The exception is super-fast high-power charging stations (up to $350 \mathrm{~kW}$ ) that allow you to charge an electric car in about 20 minutes depending on the battery capacity. However, fast charging of many electric vehicles may have a negative impact on the parameters of energy quality $[8,9]$.

One solution to overcome obstacles related to charging EVs is to replace discharged batteries with fully charged ones at a battery swapping station (BSS). Unlike charging electric vehicles with a wired or wireless method, replacing the battery could only take a few minutes. Thanks to BSSs, they could extend their journeys and reduce the time needed for further driving [23].

\section{Attempts to implement battery swapping in practice}

In the early 1900s, manual battery swapping services were first proposed to overcome the limited range of EVs. This solution was popular until the mid-1920s [15].

In 2007, the company Better Place was founded. It provided the first commercially implemented automatic battery swapping service, but it was only available for electric cars - it was not implemented for heavy vehicles (buses and trucks). However, the company declared bankruptcy in Israel in May 2013, Mainly due to a flawed strategy of building large battery swapping stations in selected geographic locations. Users were often forced to travel long distances to swap batteries, which resultied in their dissatisfaction. Although the Better Place company went bankrupt, it demonstrated that automation of battery swapping is feasible in practice. Battery swapping technology for electric buses was first commercially deployed by China in 2008. During the Summer Olympics, batteries were replaced in about 50 buses running on various routes. Since then, battery swapping in such artykuł recenzowany/revised paper vehicles has been widely implemented in China, Japan, and South Korea [17, 26].

In 2014, the Chinese company NIO undertook the dissemination of battery swapping technology (NIO Power Grid technology). It offers a combination of multiple energy charging solutions focused on improving the user experience. The core of this strategy is based on NIO's chargeable, replaceable and upgradable smart energy service system. The company announced that by October 5, 2020, the total number of electric vehicle battery swapping services in China reached 1 million. This is twice as many as on May 25, 2020. This shows how fast the demand for this service is growing. Since spring 2020, NIO has also increased the number of battery swap stations from 131 to $155[17,26]$

\section{Battery swapping methods}

The following are the various swapping methods, which are classified according to the location of the battery in the vehicle and the robotic arm's application point $[1,2]$ :

- bottom swapping is for vehicles with a battery that is located at the bottom of the vehicle. The swapping station is designed such that the vehicle is parked on a raised platform and the batteries are switched from the bottom using a robotic arm and other accessories that are usually located below ground level,

- top swapping: This is more widely seen with electric buses, where the batteries are mounted on top and the rooftop opens as the bus arrives, allowing the swapping to be done by a robotic arm,

- sideways swapping is commonly seen in buses and other vehicles where the sideways configuration is the most practical,

- rear swapping is seen in vehicles where the battery is mounted backwards. Typically in the case of vehicles with a big trunk.

\section{The principle of operation of battery swapping stations}

In order to establish and successfully implement battery swapping technology for electric vehicles such as cars, vans, and buses, extensive planning must be carried out, covering all necessary requirements, from the availability of batteries and chargers to the storage and management of data via the cloud and communication between components so as to ensure interoperability. BSSs can only operate successfully if there is continuous communication between the different components of the system (a vehicle, the BSS and information system). The information system is used to communicate with both the vehicle and the station [2]. 
The vehicle communicates with the information system using the WAVE communication system (integration of several communication networks into one), while the station uses local Internet access. When the battery charge of the vehicle is low, the information system receives a notification from the vehicle requesting a battery swapping service. The information system informs the station of the location of the vehicle and the estimated time of arrival so as to prepare an available battery until the vehicle arrives at the station. When the vehicle arrives at the station, the driver swipes one's membership card and the information system verifies all relevant data contained therein This data includes information about the vehicle, battery, swapping history, completed transactions and other relevant information. All data must then be archived in the cloud and be accessible to the station owner and customer to ensure full transparency of procedures. Once the swapping is completed, the discharged battery is monitored for state of charge, degradation level, battery age, or number of charge and discharge cycles completed $[1,2]$.

The main components of the charging station include:

- a control room (controlling and monitoring the overall operation of the BSS),

- charging racks coupled with battery racks,

- a swapping track (the zone where the batteries are located during the swap),

- a swapping lane (the road where the vehicle is during the swap),

- a swapping robot,

- battery and charger service room,

- a service room for other BSS components.

In the BSS, the driver who arrives first should have priority compared to those who arrive later as is the case at conventional filling stations. In order to meet the demand of all customers approaching the BSS, it is necessary to recharge the batteries immediately after the swap so that they are available for the next customers. An integrated BSS should maximise the range with minimal waiting time for battery swapping.

In the literature, there are models presented where discharged batteries are transported to a battery charging station and after recharging, they are transported to the BSS again. The idea of this approach is presented in Fig. 1. Transporting a large number of centrally charged batteries usually requires the use of a logistics system. The battery charging strategies and schedules, location of BSSs as well as their construction have received much attention from researchers [3, 10, 13, 20-22, 24].



Fig. 1. An approach of battery swapping with the use of an independend battery charging station
Due to constraints such as a geographical location, a limited availability of BSSs and overcrowding at stations, there is a need to design a more flexible and efficient EV battery swap architecture. Two modes of battery swapping can be distinguished - passive mode and active mode. In passive mode, the goal of having enough energy to drive an EV anytime and anywhere is not realized. Drivers must travel to the BSS to replace the battery pack. Due to the limitations of the location of the station and the number of existing batteries, there may still be a long waiting time for an available battery at that time [2].

In the active mode, battery swapping is performed using an additional vehicle that pulls up to a vehicle with a battery that is near or discharged. Recently, a new high-speed EV battery swapping device has been developed [19]. Such a device can be mounted on a vehicle that is converted into a mobile BSS. The battery removal and installation operations take place at the same time. Thus, the whole swapping process is very fast and takes only a few minutes (approximately 3 minutes in the experimental environment). Using a van as the BSS, the exchange can be carried out at any time and any place.

\section{Advantages of battery swapping stations}

As shown in Fig. 1. battery swapping requires mutual interactions between a power system, an EV owner, and the battery swapping station.

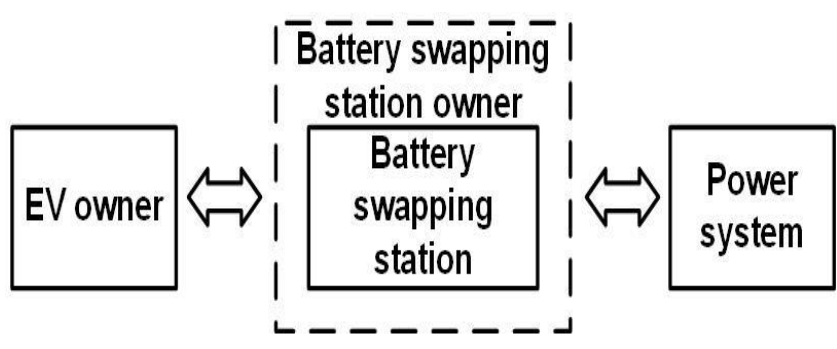

Fig. 1. Diagram of the interdependence of the electric vehicle owner, the battery swapping station owner, and the power system

The EV owner would like to replace his discharged battery with a fully charged one in the shortest time possible and move on while the BSS owner considers the most favorable electricity price for him to recharge the discharged battery and minimize the associated costs. Also important is the inherent interdependence between the BSS and the power system.

The behavior of EVs owners is unpredictable, and there are limited options for coordinated charging and discharging of grid-connected EV batteries at this time [7]. Uncontrolled charging of plug-in EVs might have a significant impact on the power system as they can contribute to load growth during peak demand. A battery swap solution offers a controlled charging strategy in terms of scheduling battery charging time without plugging in and immobilizing an entire EV for more than 20 minutes. Charging stations for the batteries themselves or battery swap stations that are also charging stations are able to defer charging to off-peak demand hours, which can solve the grid overload problem $[4,25]$.

From the power system's point of view, BSSs are a large flexible load. The energy storage capability of EV batteries provides an excellent opportunity for the owner of the BSS to offer grid services. By controlling the charging and discharging times of the batteries, the potential peak demand or overload caused by the increasing penetration of electric vehicles can be flattened. This can be achieved by setting an intelligent charging schedule without having to upgrade the current grid infrastructure. EV batteries can also help regulate frequency of a grid.

With a rapidly growing market for EVs, the need for fast chargers could become a major concern for consumers. To keep up with technological advances, infrastructure will need to be upgraded on the household side as well as at public charging stations. In this respect, battery swap stations are superior 
to traditional charging infrastructure because upgrades are only needed at the swap station location.

From the EV owner's perspective, battery swapping technology has several key advantages:

- lowering the price of the electric vehicle (the exchange stations own the batteries),

- reduced concern about battery life (use of advanced charging strategies),

- reduced cost of infrastructure upgrades.

\section{Challenges of battery swapping stations}

Speed is the biggest advantage of battery swapping. The whole operation can take a few minutes, which is about the same time as it takes to fill up a vehicle with a combustion engine. Another advantage of this solution is that the owner does not have to leave the vehicle to change a battery. He does not have to touch publicly accessible wires, buttons or display, which greatly facilitates social distance. However, the issues of battery swapping are more complex and have many challenges.

- Infrastructure

The infrastructure required to implement this solution is much more complex and costly than charging batteries at conventional charging stations. The difference between the BSS and a charging station is that the demand of the BSS can be continuously controlled. Furthermore, to meet the daily demand of any station, the number of charged batteries should always exceed a certain percentage of the daily demand. One possible strategy is to have one battery in the vehicle and another at the swap station, i.e. two batteries for each car [16]

- Feasibility

The design of batteries as well EVs themselves is currently one of the biggest obstacles to the battery swapping technology. During the battery swapping process, sparks can occur and contacts can degrade. The design of the battery pack should consider the reliability and safety of the vehicle owner when removing the battery pack and placing it back into the vehicle $[5,14]$.

- Interchangeability

The compatibility of the batteries as well as the battery swapping technology itself can ensure the success of this solution and make it dominant in the market. The main requirement is the availability of similar interchangeable battery packs from different manufacturers, which of course requires their common agreement. This might cause limitation of innovation and battery development will state as cell manufacturers, at the end of the product chain, will have to design standardized cells. It can be argued that there could be different power segments for a set of batteries, but this would create a supply and demand problem, as well as possible compatibility issues with vehicles that cannot use higher or lower power batteries.

- Battery degradation

The range of an electric car decreases as the battery deteriorates. Customers will mostly demand the newest batteries possible because they will provide more range compared to batteries that have been around longer. For this reason, the use of a particular battery in battery exchange stations can be quite short despite favourable charging conditions. However, such batteries can later be used as energy storage from renewable energy sources [18].

- Battery ownership

In the current model, the vehicle owner owns the battery. If BSSs were to become more popular, vehicle owners would have to buy an additional battery or rent one. It also seems interesting to be able to buy an electric car without owning the battery. This has several advantages. Since the vehicle owner would not own the battery then the electric car would be less expensive. The owner could pay the cost of leasing the battery along with the cost of charging and replacing the battery at the station. This could be charged each time the battery is replaced or could be, for example, a monthly fee. A form of long-term leasing could be expensive because the costs include a minimum of two sets of batteries and the service fee of the swapping station (conventional station charging requires only one battery, purchased with the car) [2].

\section{Battery swapping stations for public transport}

One of the most important and widely used means of public transportation is city buses. Due to their economic feasibility and their ability to serve almost all possible urban routes with little maintenance, they are very popular. The characteristic features of buses are as follows [12]:

- they drive predetermined routes with a specific schedule,

- they run almost exclusively during the hours of transport services,

- they stop for a short break between routes, which means that after the end of one route the bus is immediately prepared for the next route with a minimal stopping time. This is to maximize the utilisation of the bus fleet without keeping them at the depots for long periods of time.

These features can be interpreted in two ways and can be arguments for, but also against, electrification of public transport. A serious issue that needs special attention is the fastest possible recharging of the bus batteries. A battery swapping may then be necessary to avoid schedule delays and to ensure the highest possible usability of the buses. The advantages of this solution are [11]:

- speed (compared to the various vehicle charging strategies available) which allows the consumer to continue driving without major delays,

- shortening the waiting time for the bus battery to be charged, as well as extending the life of the battery (it does not need to be quickly charged at $50 \mathrm{~kW}$ and above),

- bidirectionality of energy flow, and the ability to provide ancillary services. Batteries can mitigate issues related to the variability and uncertainty of renewable energy production.

Using a battery swapping technology can be cost-effective for bus owners, as well as for BSS owners, due to the mutually beneficial cost reductions resulting from charging the batteries during low load periods and the ability to return excess energy to the grid.

An electric bus with a replaceable battery is being developed under a Polish research project. The project is implemented by the bus manufacturer Autosan, the National Centre for Research and Development, and the Łukasiewicz PIMOT consortium [27]

\section{Conclusions}

The swapping of EV batteries is a promising alternative to traditional battery charging stations. The implementation of such a technology could positively affect the electric power system due to the possibility of implementing auxiliary services (spinning reserve, active power regulation, load balancing, reactive power compensation, support for renewable energy sources).

This paper presents aspects of the implementation of battery substations, the principle of the substation, how batteries can be replaced and the benefits of BSSs for drivers, substation owners and the power system. Furthermore, the key challenges of BSSs are discussed.

To fully use the potential of the BSS, EV batteries should be easily replaceable and accessible. One important requirement would be the establishment of consistent standards - how to replace batteries as well as battery standards. According to the author, the best strategy for using BSSs is a model where the battery is owned by the company that owns the BSS. The most important advantage, besides the reduced charging time, is that the purchase price of an EV could then be lower, which could contribute to the development of electromobility. 


\section{References}

[1] Adegbohun F., Jouanne A. von, Lee K.: Autonomous Battery Swapping System and Methodologies of Electric Vehicles. Energies 12(4), 2019, 667 [http://doi.org/10.3390/en12040667].

[2] Ahmad F., Saad Alam M., Saad Alsaidan I., Shariff S. M.: Battery swapping station for electric vehicles: oppor-tunities and challenges. IET Smart Grid 3(3), 2020, 280-286 [http://doi.org/10.1049/iet-stg.2019.0059].

[3] Armstrong M., El Hajj Moussa C., Adnot J., Galli A., Riviere P.: Optimal recharging strategy for battery-switch stations for electric vehicles in France. Energy Policy 60, 2013, 569-582 [http://doi.org/10.1016/j.enpol.2013.05.089].

[4] Banerjee A., Murali V., Venkoparao V. G.: Measuring Performance Impact of Battery Swapping on Mobility Behavior. 2018 IEEE 88th Vehicular Technology Conference (VTC-Fall), 2018, 1-5

[5] Barré A., Suard F., Gérard M., Montaru M., Riu D.: Statistical analysis for understanding and predicting battery degradations in real-life electric vehicle use. Journal of Power Sources 245, 2014, 846-856 [http://doi.org/10.1016/j.jpowsour.2013.07.052].

[6] Chudy A.: The review of selected electrical energy storage techniques. IAPGOS 9(1), 2019, 23-28 [http://doi.org/10.5604/01.3001.0013.0890].

[7] Chudy A.: Zarządzanie flotą pojazdów elektrycznych w sieciach inteligentnych - sterowanie ładowaniem oraz zagadnienia optymalizacyjne. Interdyscyplinarność w badaniach naukowych prace doktorantów Politechnik Lubelskiej. Wydawnictwo Politechniki Lubelskiej, Lublin 2020

[8] Chudy A., Mazurek P.: Electromobility - the Importance of Power Quality and Environmental Sustainability. J. Ecol. Eng. 20(10), 2019, 15-23 [http://doi.org/10.12911/22998993/112713].

[9] Chudy A., Stryczewska H. D.: Electromagnetic compatibility testing of electric vehicles and their chargers. IAPGOS 10(3), 2020, 70-73 [http://doi.org/10.35784/iapgos.1687].

[10] Feng J., Hou S., Yu L., Dimov N., Zheng P., Wang C.: Optimization of photovoltaic battery swapping station based on weather/traffic forecasts and speed variable charging. Applied Energy 264, 2020, 114708 [http://doi.org/10.1016/j.apenergy.2020.114708].

[11] Kim J., Song I., Choi W.: An Electric Bus with a Battery Exchange System Energies 8(7), 2015, 6806-6819 [http://doi.org/10.3390/en8076806].

[12] Li W., Li Y., Deng H., Bao L.: Planning of Electric Public Transport System under Battery Swap Mode. Sustainability 10(7), 2018, 2528 [http://doi.org/10.3390/su10072528].

[13] Liang Y., Cai H., Zou G.: Configuration and system operation for battery swapping stations in Beijing. Energy 214, 2021, 118883 [http://doi.org/10.1016/j.energy.2020.118883].

[14] Mahmoudzadeh Andwari A., Pesiridis A., Rajoo S., Martinez-Botas R. Esfahanian V.: A review of Battery Electric Vehicle technology and readiness levels. Renewable and Sustainable Energy Reviews 78, 2017, 414-430. [http://doi.org/10.1016/j.rser.2017.03.138].

[15] Mahoor M., Hosseini Z. S., Khodaei A., Kushner D.: Electric Vehicle Battery Swapping Station. 2017 [https://arxiv.org/abs/1710.06895]
[16] Mak H.-Y., Rong Y., Shen Z.-J. M.: Infrastructure Plan-ning for Electric Vehicles with Battery Swapping. Management Science 59(7), 2013, 1557-1575 [http://doi.org/10.1287/mnsc.1120.1672].

[17] Qi W., Zhang Y., Zhang N.: Scaling Up Battery Swapping Services in Cities. SSRN, 2020 [http://doi.org/10.2139/ssrn.3631796]

[18] Quinard H., Redondo-Iglesias E., Pelissier S., Venet P.: Fast Electrical Characterizations of High-Energy Sec-ond Life Lithium-Ion Batteries for Embedded and Stationary Applications. Batteries 5(1), 2019, 33 [http://doi.org/10.3390/batteries5010033]

[19] Shao S., Guo S., Qiu X.: A Mobile Battery Swapping Service for Electric Vehicles Based on a Battery Swap-ping Van. Energies 10(10), 2017, 1667 [http://doi.org/10.3390/en10101667].

[20] Sun B., Sun X., Tsang D. H.K., Whitt W.: Optimal battery purchasing and charging strategy at electric vehicle battery swap stations. European Journal of Operational Research 279(2), 2019, 524-539. [http://doi.org/10.1016/j.ejor.2019.06.019].

[21] Tan X., Sun B., Wu Y., Tsang D. H.K.: Asymptotic performance evaluation of battery swapping and charging station for electric vehicles. Performance Evaluation 119, 2018, 43-57 [http://doi.org/10.1016/j.peva.2017.12.004].

[22] Verma A.: Electric vehicle routing problem with time windows, recharging stations and battery swapping stations. EURO Journal on Transportation and Logistics 7(4), 2018, 415-451 [http://doi.org/10.1007/s13676-018-0136-9].

[23] Wu C., Lin X., Sui Q., Wang Z., Feng Z., Li Z.: Two-stage self-scheduling of battery swapping station in day-ahead energy and frequency regulation markets. Applied Energy 2020, 116285 [http://doi.org/10.1016/j.apenergy.2020.116285].

[24] Yang J., Sun H.: Battery swap station location-routing problem with capacitated electric vehicles. Computers \& Operations Research 55, 2015, 217-232 [http://doi.org/10.1016/j.cor.2014.07.003].

[25] Zeng B., Luo Y., Zhang C., Liu Y.: Assessing the Impact of an EV Battery Swapping Station on the Reliability of Distribution Systems. Applied Sciences 10(22), 2020, 8023 [http://doi.org/10.3390/app10228023].

[26] nio.com/blog/brief-history-battery-swapping (18.03.2021)

[27] transinfo.pl/infobus/autosan-zbuduje-elektrobus-z-wymiennymi-bateriami_more_122722 (16.03.2021).

\section{M.Sc. Eng. Aleksander Chudy}

e-mail: a.chudy@pollub.pl

He is graduated from Lublin University of Technology in 2018. In the same year he started his Ph.D. studie in the field of Electrical Engineering. Currently he works as an assistant in the Department of Electrcal Engineering and Electrotechnologies of Lublin University of Technology. His research is focused on the impact of electromobility on power quality parameters and electromagnetic compatibility.

http://orcid.org/0000-0002-3183-8450

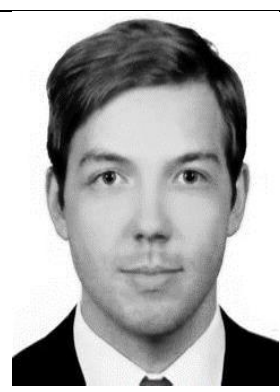

przyjęto do druku/accepted: 7.06 .2021 